Reiza Miftah Wirakusuma, Oman Sukirman, Ridwan Taufik Waliyudin, Rifki Rahmanda Putra: DESIGNING CORAL REEF TRANSPLANTATION PROGRAM WITH LOCAL COMMUNITY IN FORM OF MARINE ECOTOURISM TOUR PACKAGE

\title{
DESIGNING CORAL REEF TRANSPLANTATION PROGRAM WITH LOCAL COMMUNITY IN FORM OF MARINE ECOTOURISM TOUR PACKAGE
}

\author{
Reiza Miftah Wirakusuma ${ }^{(1)}$, Oman Sukirman ${ }^{(2)}$, Ridwan Taufik Waliyudin ${ }^{(3)}$, Rifki \\ Rahmanda Putra ${ }^{(4)}$ \\ (1) (2) (3)(4) Universitas Pendidikan Indonesia \\ reizamiftah@upi.edu ${ }^{(1)}$ oman@upi.edu ${ }^{(2)}$ \\ Submitted: 5 July 2019 Revised: 18 August 2019 \\ Accepted: 30 September 2019
}

\begin{abstract}
ABSTRAK
Sejak 1990 Pangandaran telah berkembang menjadi salah satu tujuan wisata utama di Jawa Barat yang memfokuskan pengembangannya pada wisata bahari. Perkembangan itu menarik banyak wisatawan dan berdampak pada kondisi ekosistem laut. Terumbu karang secara perlahan dirusak oleh kegiatan wisatawan, limbah plastik dan polusi, sehingga kejernihan air terdegradasi. Program ini dilakukan untuk menganalisis tingkat kerusakan terumbu karang dan kesiapan masyarakat dalam membudidayakan terumbu karang, serta menyediakan pelatihan kepada masyarakat sehingga model transplantasi akan dihasilkan. Subjek dari pelatihan ini adalah komunitas nelayan di Kecamatan Pananjung. Pelatihan disampaikan dalam tahapan: 1) identifikasi kondisi terumbu karang di Perairan Cagar Alam; 2) analisis kesiapan dan kemampuan masyarakat dalam mengembangkan budidaya terumbu karang, dan 3) pelatihan dalam budidaya terumbu karang bagi masyarakat. Sasaran dari kegiatan ini adalah untuk meningkatkan kualitas lingkungan perairan dan meningkatkan pengetahuan masyarakat setempat melalui pelatihan dalam budidaya terumbu karang. Ketika transplantasi siap, masyarakat setempat akan dapat mengembangkan usaha pariwisata mandiri, berdasarkan konservasi dan meningkatkan ekonomi masyarakat, sehingga membantu pemerintah dalam mewujudkan wisata bahari yang berkelanjutan.
\end{abstract}

Kata Kunci: Ekowisata, Transplantasi Terumbu Karang, Wisata Bahari.

\section{ABSTRACT}

Since 1990 Pangandaran has developed into one of the main tourism destination in West Java which focuses its development on Marine Ecotourism. The development drawn high number of tourists and impacted the condition of the marine ecosystems. The coral reefs were slowly being damaged by tourists activities, plastics waste and pollution, thus the clarity of the water was degraded.This Program was conducted to analyze the level of damage to coral reefs and community preparedness in cultivating coral reefs, as well as providing training to the community so that the model of transplantion would be generated. The subjects of this training were fishermen communities in Pananjung Subdistrict. The training was delivered in the stages of: 1) identification of the condition of coral reefs in the Nature Reserve Waters; 2) analysis of community readiness and ability in developing coral reef cultivation, and 3) training in coral reef cultivation for the community. The target of this activity is to improve the quality of the aquatic environment and increase the knowledge of local communities through training in coral reef cultivation. Whenever the transplantation is ready, the local community will be able to develop an independent tourism business, based on water conservation, and improve the economy of the community, thus helping the government in realizing a sustainable marine tourism.

Keywords: Coral Reef Transplantation, Ecotourism, Marine tourism. 


\section{INTRODUCTION}

Tourism development sector in Indonesia currently being developed. This sector has contributed almost $5 \%$ of national gross domestic product (GDP). The tourism sector continues to be developed considering this sector contributes to the country which is considered to affect many aspects (in route benefits) in the form of state and regional income, employment, economic development and education sector development.

The development of tourism which continues to be improved also has a negative impact if it is not managed properly. These negative impacts also received special attention, such as the shift in the value of local culture, the fading of ethics and norms, disruption of wildlife habitat, garbage and vandalism which are common today in various locations and tourism activities.

The concept of sustainable tourism is the concept of tourism development which considers the sustainability of economic (Richards, G., \& Hall, D, 2002)., social and natural aspects so that tourism is expected to become a product of environmental services that do not over exploit both natural and human resources, but are more focused or focused on the use of services. This concept is expected to be able to touch and benefit local communities and regional development not only investors from outside the tourist area.

Indonesia's potential as a maritime country and an archipelagic country that has a large number of islands and a diversity of local morphology and landscapes is the main attraction for tourism. Social and cultural potential as a result of the interaction between humans and nature also has the potential that is as good as its physical condition. Both of these potential advantages will remain and be sustainable if they are used and developed in accordance with the value of uniqueness and capacity, and vice versa the superiority of this potential will be lost if exploitation is carried out irresponsibly so that it removes the value of its attraction.
The behavior of tourists visiting needs to get attention, because tourism activities are known as activities carried out for pleasure purposes. Tourism activities must have a positive impact on better tourist behavior and make tourist areas not only as recreational facilities but also as entertainment facilities. Tourism products and activities must be packaged by combining educational and entertainment activities so that they have more meaning and experience for tourists.

Pangandaran Regency is one of the regencies in West Java with very attractive natural physical conditions that have high tourism potential, unique and typical of the South Coast Coast region of Java as well as interesting local cultural activities. Pangandaran Regency as a New Autonomous Region (DOB) in West Java has one of the tourism icons in the province so it is very effective and makes a factor of strength in terms of tourist attraction for this area. The potential of coastal tourism areas as a means of education is actually high enough. With tourism activities in nature, tourists can learn about the diversity of vegetation and animals and their habitats, observe the ecological cycle and the linkages between natural components and take action to care for the environment.

A variety of environmental education values can be learned during natural tourism activities such as maintaining the cleanliness of the area, avoiding water and air pollution, avoiding destruction of biota and vegetation, studying the life of forest ecosystems with their unique animals, observing beauty and natural phenomena while admiring the greatness of the Creator, can be stimulated by using appropriate means and media. Through this service, it is expected to produce development models that sustainable, with consideration to the economic, ecological and comfort aspects of tourists.

\section{LITERATURE REVIEW}

Coral reefs are dynamic ecosystems with a wealth of biodiversity and high productivity, therefore coral reefs have a 
Reiza Miftah Wirakusuma, Oman Sukirman, Ridwan Taufik Waliyudin, Rifki Rahmanda Putra: DESIGNING CORAL REEF TRANSPLANTATION PROGRAM WITH LOCAL COMMUNITY IN FORM OF MARINE ECOTOURISM TOUR PACKAGE

significant role. Ecologically, coral reefs are places where both animal organisms and plants seek food and shelter. Physically becoming a protective beach and the life of a shallow water ecosystem from marine abrasion (Suryanti et al., 2011).

1. In the management and utilization of coral reefs, there are many different destructive factors in coral reefs. These factors can be described as follows (Kholish, 2003; Johan, et al., 2007; Sunarto, 2006; Yusnita, 2014; and Pasanea, 2013): Collecting coral for building materials

2. Collecting coral for decoration

3. Catching reef ornamental fish

4. Catching non-fish biota on the coral reef ecosystem

5. Tourism activities

6. Development on the coast such as ports, hotels, restaurants or reclamations

7. Development on land especially near river flows that empties

8. Pollution of river, coastal and sea waters

9. Sedimentation

10. Climate change is like the El-Nino phenomenon

11. Natural disasters such as earthquakes and tsunamis.

12. Predation or damage to coral reefs by some polyp-eating animals

In developing marine tourism requires the concept of ecotourism which has several principles, namely (Suhandi, 2001): (1) Conservation Principles; fostering concern, responsibility, and commitment to nature conservation and development following ecological principles. (2) Principles of Community Participation; basically, the knowledge of the local community. Therefore the involvement of the community in a participatory manner is absolute, starting from the planning level to the management level. (3) Economic Principles; ecotourism provides an opportunity to benefit the organizers, the government and the local community. Organization that pays attention to the principles of ecotourism, realizing a sustainable economy. Wirakusuma (2014) also referring the benefit of creative economy when the local community inventing new ideas for marine conservation. (4) Principles of Education; ecotourism activities provide added value to visitors and the local community in the form of knowledge and experience. This added value affects changes in behavior of visitors, the public, and tourism developers so that they are aware and more respectful of nature, historical and cultural heritage values. (5) Tourism Principles; creating a sense of security, comfort and providing understanding and experience for visitors.

\section{RESEARCH METHOD}

This service program was conducted in Pangandaran Regency, precisely in the Pananjung Nature Reserve. The waters on the Pananjung Island Nature Reserve are divided into eastern and western regions. The western part has 1 snorkeling spot, while the eastern part has 2 snorkeling spots. The survey for the sinking of coral demonstration plots was carried out in the East Coast region because according to interview data obtained from key informants namely Pangandaran people who work as snorkeling facilitators and also the Pangandaran Community Care Group, in the area the coral reef conditions are better than West Coast Beach, traffic the tourist transport vessels are not high, and the condition of the waters is right for the attempt to sink the coral demonstration plot.

The selection of the location of this service program has a background that originates from the relationship between UPI and Pangandaran Regency itself. In connection with the research umbrella of the University of Indonesia in the Resort and Leisure Management Study Program road map it is stated to prepare based on the vision of the institution as a center for tourism education that excels in the planning, management and development of resorts and recreation. 


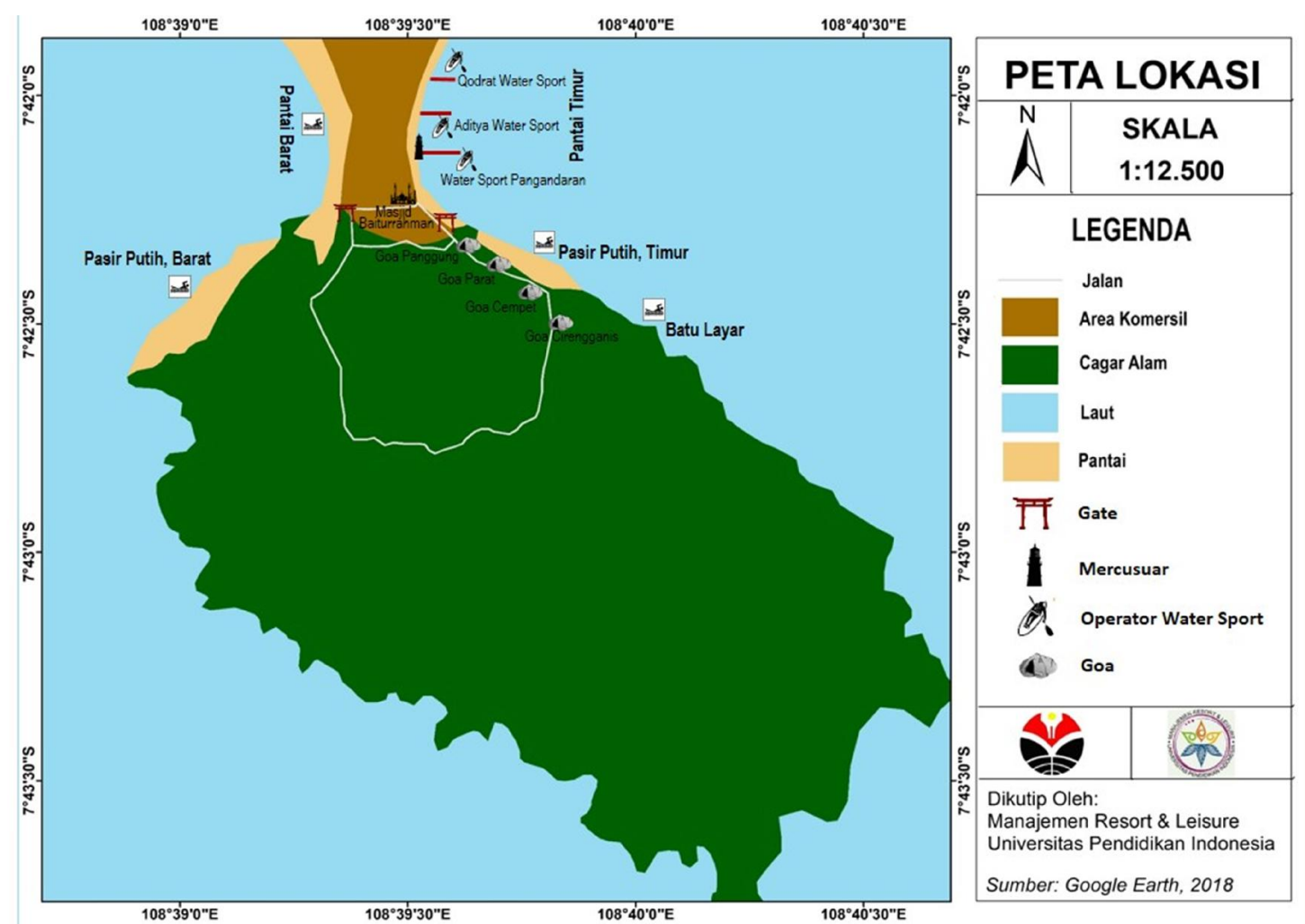

Picture 1. Map of Pananjung Nature Reserve as a transplantation Target (PasirPutih, Batu Layar 1, \& Batu Layar 2 spot)

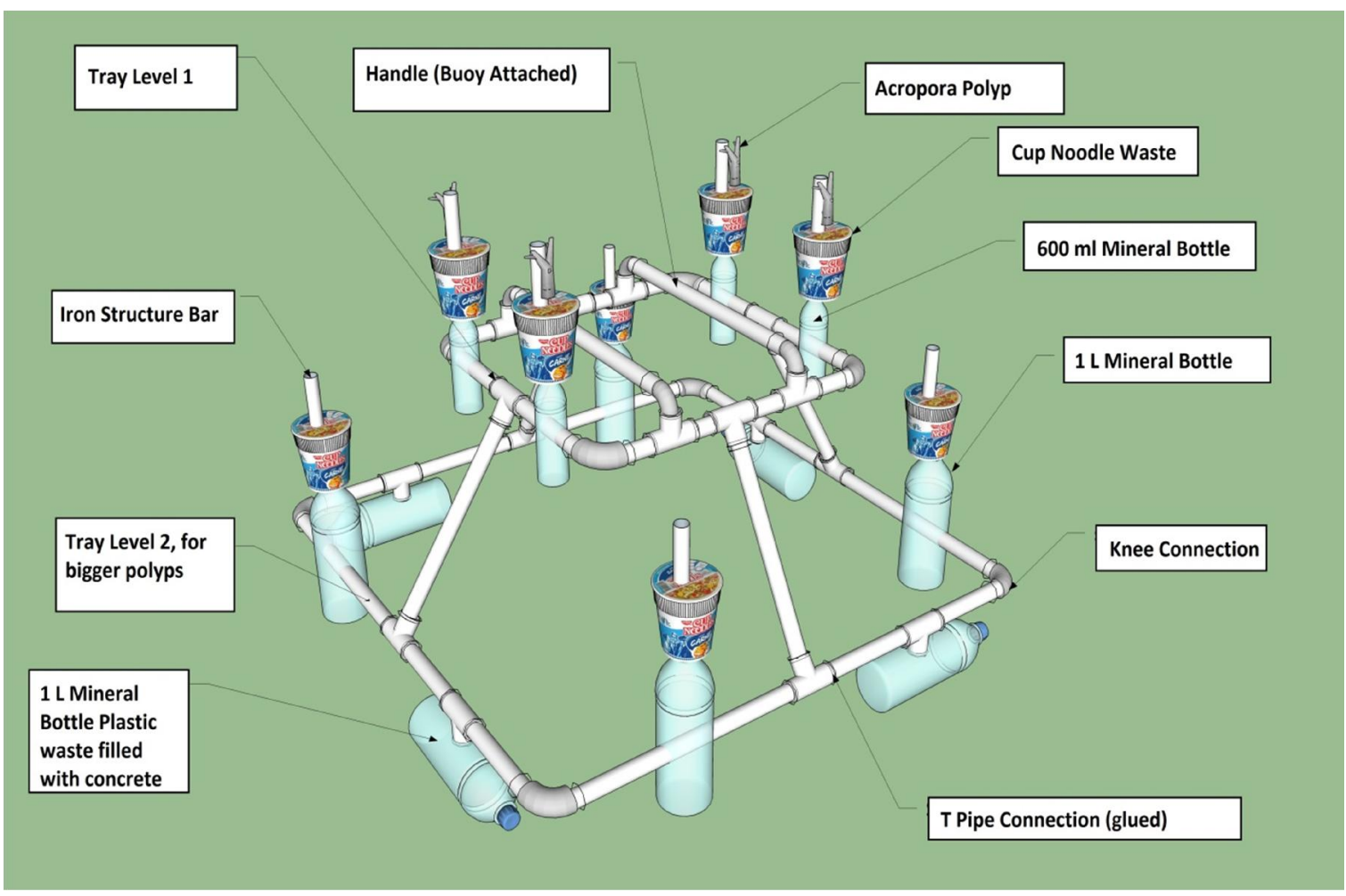

Picture 2. The Design of Coral Transplantation Demonstration Plot (2018) 
Reiza Miftah Wirakusuma, Oman Sukirman, Ridwan Taufik Waliyudin, Rifki Rahmanda Putra: DESIGNING CORAL REEF TRANSPLANTATION PROGRAM WITH LOCAL COMMUNITY IN FORM OF MARINE ECOTOURISM TOUR PACKAGE

Coral plots demonstration plots are made of plastic pipes are joined together to form a pyramid. Furthermore, in each plastic stem there is a cement pot using used waste media (bottles of used mineral water packaging and used containers of instant noodle packaging) which are useful as substrate or planting media which are then planted with coral seedlings. The coral reef seeds are then planted under the sea so they can develop. Tourists will be able to bring and plant the reef seeds in the middle of the sea and install them in the sea.

This activity requires students to think academically, analytically and can be comprehensive and cooperate with the government, especially related agencies in Pangandaran Regency. It was also acknowledged

The targets in this activity will be aimed at the productive age group. In addition, the profession or livelihood as a fisherman and service sector is very potential as the subject of this activity. So the target is focused on 3 organizations consisting of KMPP (Komunitas Masyarakat Peduli Pangandaran), OP3 (Organisasi Perahu
Pesiar Pangandaran) and Water Sport Operators to facilitate the team in carrying out and achieving the objectives of the activity.

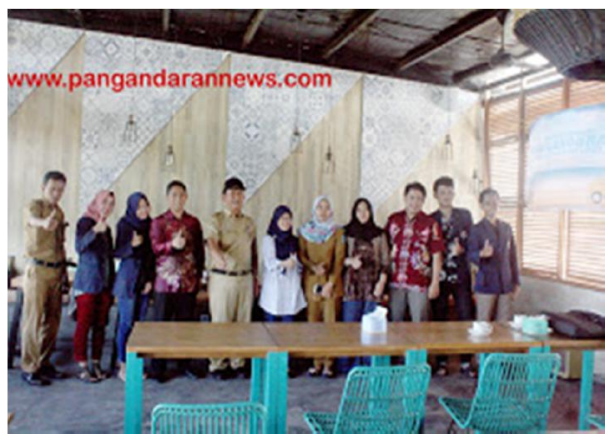

Picture 3. Management of Resort and Leisure UPI Bandung Field Project Study

Source: www.pangandarannews.com

The picture above are the documentation when the Tourism Government Organization (Dinas Pariwisata Pangandaran) had a brainstorming ideas to develop marine tourism packaging.

The steps of this community service activities are arranged as in the table below:

Table 1. Stages of Training Activities

\begin{tabular}{|c|c|c|c|}
\hline No & Activity & Time & Info \\
\hline \multirow[t]{3}{*}{1} & Preparation & & \\
\hline & $\begin{array}{l}\text { Coral reef condition and } \\
\text { identification }\end{array}$ & Sunday 1-3 Mei 2018 & DKP \\
\hline & $\begin{array}{l}\text { Collect types of coral } \\
\text { reefs to be used as seeds } \\
\text { (acropora sp.) }\end{array}$ & Sunday 4 Mei 2018 & $\begin{array}{c}\text { KMPP, OP3, \& } \\
\text { Watersport Operator }\end{array}$ \\
\hline 2 & $\begin{array}{l}\text { Identification \& analysis } \\
\text { Survey the characteristics } \\
\text { and knowledge of the } \\
\text { community }\end{array}$ & Sunday 1-2 Juni 2018 & $\begin{array}{c}\text { KMPP, OP3, \& } \\
\text { Watersport Operator }\end{array}$ \\
\hline \multirow[t]{3}{*}{3} & $\begin{array}{l}\text { Implementation } \\
\text { Coral Reef Cultivation } \\
\text { Training (Hard Coral) for the } \\
\text { community }\end{array}$ & $\begin{array}{c}\text { Sunday } 24 \text { September } \\
2018\end{array}$ & $\begin{array}{c}\text { KMPP, OP3, } \\
\text { \&Watersport Operator }\end{array}$ \\
\hline & Preparation of reports & 15-27 Oktober 2018 & PKM Team \\
\hline & $\begin{array}{l}\text { Plans for Making } \\
\text { Educational and }\end{array}$ & $\begin{array}{l}\text { Wednesday } 31 \\
\text { Oktober } 2018\end{array}$ & PKM Team \\
\hline
\end{tabular}


Journal of Indonesian Tourism, Hospitality and Recreation --- Volume 2, No. 2, October 2019

eISSN: 2654-4687 ----- pISSN: 2654-3893

\begin{tabular}{|c|c|c|c|}
\hline No & Activity & Time & Info \\
\hline & $\begin{array}{l}\text { Conservation Packages } \\
\text { (Coral Gardening) } \\
\text { synergized with snorkeling } \\
\text { activities }\end{array}$ & & \\
\hline & Make a proposal for & & PKM Team \\
\hline & $\begin{array}{l}\text { Intellectual Property Rights } \\
\text { from Coral Gardening } \\
\text { activities }\end{array}$ & $\begin{array}{r}\text { Saturday } 15 \\
\text { December } 2018\end{array}$ & \\
\hline
\end{tabular}

Source: Processed Results of PKM Team, 2018

\section{RESULTS}

The results achieved in this activity are answers to a predetermined problem formulation, namely: 1) Obtaining information about the condition of the coral reefs of Pananjung Nature Reserve and community readiness in coral reef cultivation, 2) Increased understanding and skills of the community regarding coral reef cultivation , 3) The production of a gardening coral demonstration plot that can be used as an example for the community and developed into marine ecotourism activities, and 4) The acquisition of HKI related to the model of coral gardening for. The following are the results achieved based on a series of processes that have been carried out by the team:

\section{Condition of Coral Reefs in the Waters of Pananjung Nature Reserve Island Pangandaran District}

Existing conditions of coral reefs in the island waters of Pananjung Nature Reserve in Pangandaran Regency after the team made observations on September 23, 2018 to several snorkeling points (Marine Park Coral Reef, Batu Layar 1, and Batu Layar 2) and interviews with OP3 (Pangandaran Cruise Boat Organization) , then obtained information that the condition of the majority of its coral reefs can be fairly unhealthy, there are many faults, bleaching, and the density level of coral reef cover is very tenuous to rare. Even the FADs for coral reef cultivation belonging to the KMPP (Pangandaran Community Care Community) were found with balokan material which was casted and arranged in a terraced manner, however, the conditions were destroyed, allegedly all of this was due to tidal waves and human factors that tied the cage anchoring device to FAD.

Poor physical condition in Pangandaran is also one of the constraints in the process of implementing coral reef demonstration plots, which include visibility within the layout of only $<2$ meters, strong underwater currents, no variety of ornamental fish, and waves are quite high. According to Suharsono (1998) it is known that turbidity of waters can inhibit the penetration of light entering the waters and will affect coral life because corals cannot carry out photosynthesis properly, waters that have high turbidity and sedimentation tend to have low diversity and live coral cover.

Based on additional information from a brief discussion with KMPP (Pangandaran Community Care Community), OP3 (Pangandaran Cruise Organization), and several representatives from the waterspot operator on September 24, 2018 in addition to natural or weather factors, human factors are also thought to have a significant influence on coral reef ecosystems in Pangandaran, such as the awareness of the community, fishermen, tourism entrepreneurs in Pangandaran who still care less about coral reef ecosystems such as dumping waste into the sea, fishing in the snorkeling spot by going barefoot and stepping on existing reefs, so guidance is still needed towards the general public and special attention from the government directly. The mindset of people who are only money oriented do not yet have the awareness that the importance of coral 
Reiza Miftah Wirakusuma, Oman Sukirman, Ridwan Taufik Waliyudin, Rifki Rahmanda Putra: DESIGNING CORAL REEF TRANSPLANTATION PROGRAM WITH LOCAL COMMUNITY IN FORM OF MARINE ECOTOURISM TOUR PACKAGE

reefs is not only beautiful for tourists but also for the majority of the people who are traditional fishermen will also be affected because the fish will also multiply more. Even those who become facilitators for tourists doing snorkeling activities also still need guidance to encourage tourists what equipment to use and what things should not be done when in the water such as stepping on a coral reef barefoot.

Then the water point was found in the Marine Park Coral Reef area for the first attempt to sink the demonstration plot by the team, where it also became a snorkeling spot that was usually served to tourists on the East Coast. The sinking point of the demonstration plot is at a depth of approximately 2-3 meters and is located at 120 meters from the Goa Panggung tourist attraction point, more precisely at the coordinates of $7^{\circ} 42^{\prime} 16^{\prime L S} \& 108^{\circ} 39^{\prime} 42^{\prime \prime}$ BT.

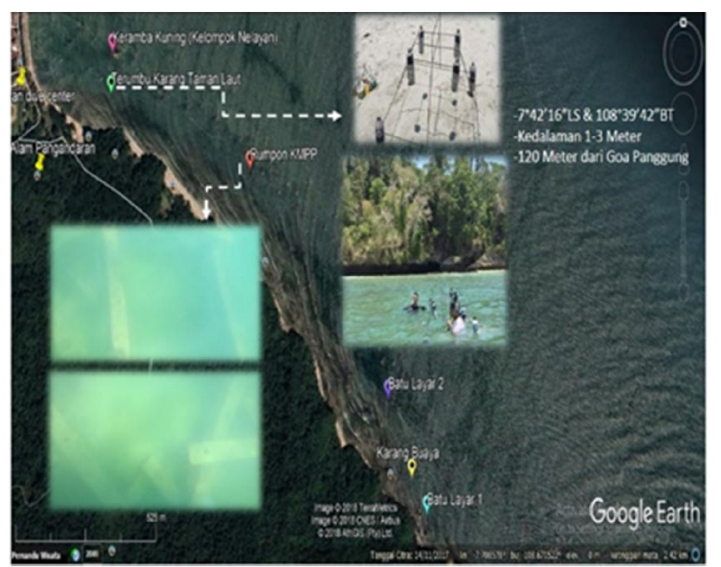

Picture 4. Coral Reef Spot Distribution

Map and Demonstration Plot Sink Source: Processed Results of PKM Team, 2018

The output of this service activity is, among others, the Demonstration Coral Plot (demplot coral). Demonstration plots are a method of restoring coral seedlings, to be able to become coral reefs. The following are the construction materials from the demonstration plot such as Pipe, empty Mineral Bottle $1000 \mathrm{ml}$. Instantly packaged cup noodles, Cement, and last is the Iron Wire.

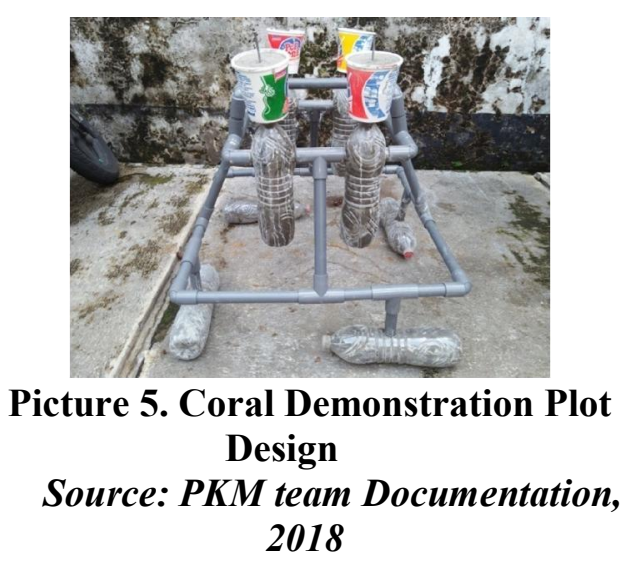

2. Level of Public Knowledge Regarding Aquatic Conservation and Coral Reef Cultivation Technique on Pananjung Nature Reserve Island, Pangandaran District

Basically the demographic conditions of the people in Pangandaran Regency are migrants and have the livelihood of fishermen and watersport operators. Some people actually know a lot about fish and coral reefs, including knowing how to grow coral reefs, but due to the high need for fish so that competition arises that tends to only emphasize fish income (for fishermen) and tourist quantity income (for activity operators). tourism) so that various instant ways are done and this is done in a way that tends to damage the coral reef ecosystem that is there. If this is not balanced with the correct conservation method, over time the coral reefs around Pangandaran will be completely extinct and it is not possible for fish around the coast to be hard to find.

Based on the implementation of the coral reef cultivation program which was held on September 24, 2018, which was located at Hotel Setia Restaurant Pangandaran Jalan Kidang Pananjung, information was obtained, namely that the general public was not yet aware of the importance of conservation or sustainability of the Pangandaran marine ecosystem, especially related to coral reefs. Only a handful of people are aware and also come down to preserve the coral reefs in Pangandaran such as KMPP (Community Care for 
Pangandaran). However, it is certainly a problem if there is no support from other communities in general.

The problems encountered are directly proportional to the level of knowledge and public awareness of conservation that is still low, namely the amount of waste from the general public, fishermen, and even to providers of accommodation services. Then the absence of good management from the Pangandaran community who works as an operator of snorkeling services that is welleducated about things that should not be done by tourists during snorkeling is still not maximal, it is also a serious problem, considering the target of tourists who can make millions of coral reefs annually in Pangandaran is threatened especially if there is no visitor management for snorkeling tourism activities such as assistance by the service provider before, for a moment, and after snorkeling, calls are not allowed to step on the coral reef barefoot, and are not allowed to feed fish using bread. According to Yusnita (2014) tourism activities can be one of the factors causing damage to coral reefs caused by marine tourism activities in general, namely the physical contact of tourists with coral reefs either intentionally or unintentionally. Physical contact includes kicking, stepping on, holding, taking marine life and diving equipment in contact with coral reefs.

Other problems that are directly proportional to the low level of knowledge of the Pangandaran community towards the conservation of coral reefs are the presence of people who fish octopus, caroang fish, and so on in the snorkeling area by stepping on existing reefs. as well as the intensity of small ships passing by in the snorkeling spot or coral reefs.

Future expectations from the results of the discussions conducted by the Pangandaran community team and representatives consisting of KMPP, OP3, and Operator Watersport on September 24, 2018, namely the need for direct dissemination to the community in general, fishermen, snorkeling service providers, and other relevant parties held directly by the central government so that the issue of coral reefs is of particular concern in Pangandaran Regency. The construction of facilities in the waters such as the barrier steps to change the anchor pattern of fishermen to become anchor anchors, the existence of facilities such as garbage cleaning boats, the existence of strict regional regulations to preserve coral reefs in several snorkeling spots.

Every stakeholder must work together to build cooperation and commitment to the preservation of existing coral reefs. Because seyogiya, if together preserve coral reefs, certainly not only will it affect the sustainability of ecosystems in the waters, but it will also have an impact both socially and economically (UNWTO, 2002).

3. Level of Public Knowledge Regarding Aquatic Conservation and Coral Reef Cultivation Technique on Pananjung Nature Reserve Island, Pangandaran District

Based on the findings of fundamental problems, including the amount of waste produced by tourists and also the people that disrupt the underwater ecosystem, then to bridge the interests of tourism activities, community economics, and also environmental degradation, the team initiated creating coral reef demonstration plots where the ballast uses cement which is filled with bottled waste used in mineral water and its substrate (pot container for coral seedlings) using waste from ready-made instant noodles containers.

After the design of the demonstration plot was assembled, then the coral seedlings that had been collected and purchased by tourists were then tied to a substrate or container made of instant noodle containers ready for serving, then they could be taken with the passenger boat and submerged by snorkeling spots where the waters were calm and not too deep. however, it remains in the zone which is not affected by the tides / remains inundated even though the sea is receding. 
Reiza Miftah Wirakusuma, Oman Sukirman, Ridwan Taufik Waliyudin, Rifki Rahmanda Putra: DESIGNING CORAL REEF TRANSPLANTATION PROGRAM WITH LOCAL COMMUNITY IN FORM OF MARINE ECOTOURISM TOUR PACKAGE

4. The Form of Implementation of Coral Reef Cultivation which is suitable for tourists who have an ecotourism nuance on Pananjung Nature Reserve Island, Pangandaran District

Before being applied directly to tourists, the implementation of coral reef cultivation efforts is carried out in several forms and several stages. The first was carried out with Coral Reef Cultivation Training activities with the aim of being Pangandaran people organized as KMPP (Pangandaran Community Care Community), OP3 (Pangandaran Cruise Boat Organization), and watersport operators in the form of Focus Group Discussion. After the socialization to identify constraints in the cultivation of coral reefs in Pangandaran, a solution was obtained from the discussion which was then poured into a follow-up program which was focused on the search for coral seedlings as shoots for Coral Gardening and fostering the Making of Tourism and Education Conservation Packages (Coral Gardening) which is synergized with snorkeling activities.

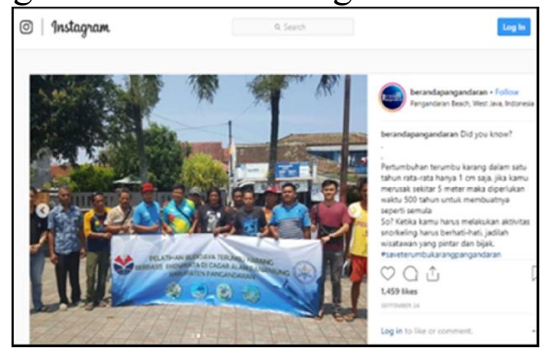

Picture 6. Post-Training

Documentation of Coral Reef Cultivation Source: www.instagram.com/BerandaPanga ndaran

So that later the output in the series of programs that have been implemented is expected to become a patent (demplot coral) product right and can become a new tourism package, namely ecotourism-based snorkeling tourism activities that can be purchased by tourists. Where the package is in addition to benefiting the community because of the creation of unique tourist activities that can be sold, it can also provide a different new experience for tourists where tourists are invited to buy tour packages. Then, this tour package is also good for sustainable underwater ecosystems in Pangandaran, especially in the Pananjung Nature Reserve area. In this case, it is also necessary to monitor evaluations with periodically by partnering with communities in Pangandaran, so that the efforts to conserve coral reefs are sustainable.

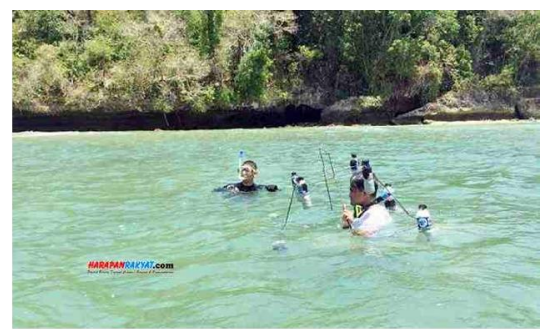

Picture 7. The submerging process of the Coral Demonstration Plot

\section{Source: harapanrakyat.com}

\section{Supporting Factors and Constraints}

\section{Supporting Factors}

a) There are organizations / community groups participating in the implementation of training in coral reef cultivation. Such as, Pangandaran Community Care Group, Boat Organization, Pangandaran Cruise \& Water Sport Operator Pangandaran.

b) The amount of input and direction from the fishermen regarding the technicalities of a suitable coral reef cultivation program and can be carried out in the pananjung nature reserve in Pangandaran district.

c) Support from print media and local online media that helped publish the process and results of an ecotourismbased coral reef cultivation program in Panganan's Pangandaran regency.

\section{Constraints}

a) There is no youth organization / group that really cares and focuses on the condition of Pagandaran coral reefs.

b) Physical factors in Pangandaran that do not support activities, such as 
strong underwater currents, underwater visibility is only $1-2$ meters, high waves, strong winds. And artificial factors such as public awareness related to water cleanliness and maintaining a lack of environment. Evidenced by the presence of a lot of garbage in the location of the waters which is recognized as garbage, besides coming from tourist activities, also from the community or fishermen, also found some fishermen who do their activities in snorkeling spots.

c) Partners who are invited to collaborate in the implementation of ecotourism-based cultivation, namely (fishing communities \& water sport operators) tend to still be monitored or monitored periodically so that the implementation is correct and sustainable, because the character of partners has so far been more biased towards profit.

\section{FOLLOW UP PROGRAM}

The follow-up program in this study includes a refinement program from the results of a series of activities carried out by the research team, at least pointing to the core of defined outcomes including information on the existing conditions of coral reefs in the waters of Pananjung Nature Reserve on some snorkeling points (Coral Reefs) Taman Laut, Batu Layar 1, and Batu Layar 2) the condition of the coral reefs has many faults, bleaching, and also there are FADs for KMPP's coral reef cultivation with conditions that have been destroyed, presumably all of this is due to natural factors namely the recent tidal wave in Pangandaran. The visibility in the display is $<2$ meters, the underwater current is quite strong, there is no variety of ornamental fish, and the waves are high. Then the water point was then called the Marine Park Coral Reef for sinking the demonstration plot, where it also became a snorkeling spot that was usually served to tourists on the East Coast with a depth of approximately 2-3 meters and located at 120 meters from the tourist attraction of Goa Panggung.

The understanding and skills of the community regarding the cultivation of coral reefs is very important aiming to provide awareness to the community concerned. However, it is felt that it is still necessary to collaborate with the central government to touch more on the general public routinely monitored and evaluated. Due to the implementation of counseling there were obstacles and expectations from several participants, including the lack of awareness of the general public, there was no direct action from the central government regarding the disposal of waste / garbage, both from accommodation, tourists and the community.

The production of a coral gardening demonstration plot that can be used as an example by the community and developed into marine ecotourism activities is the outcome of this service activity. The design of the coral demonstration plot using raw materials by collaborating waste water bottles with mineral water and instant noodle packaging waste is one of the breakthroughs in overcoming problems related to waste in the Pangandaran area (zero waste management), this coral demonstration plot is expected to reduce the amount of waste in the Pangandaran beach area, it is also expected to increase public awareness of environmental concerns including concern for the protection of existing coral reef ecosystems.

After obtaining the existing conditions of Panganan's Pananjung Nature Reserve and understanding of coral reef cultivation to community representatives and providing coral reef cultivation programs using ecofriendly coral demonstration plots. The follow up is that the community represented by the Pangandaran Community Care Group, Pangandaran Cruise Boat Organization and Water Sport Operators can work together to apply the coral reef cultivation program which if properly managed and properly 
Reiza Miftah Wirakusuma, Oman Sukirman, Ridwan Taufik Waliyudin, Rifki Rahmanda Putra: DESIGNING CORAL REEF TRANSPLANTATION PROGRAM WITH LOCAL COMMUNITY IN FORM OF MARINE ECOTOURISM TOUR PACKAGE

assessed, this program will benefit greatly, including:

1. Improve the condition of the waters around the Pananjung Nature Reserve.

2. The community will benefit financially because there are new tour packages that can be sold.

3. Education and new experiences for tourists.

Then the planned follow-up program includes the determination of IPR coral demonstration plots and the establishment of tourism packages that can be sold by the community, namely ecotourism-based snorkeling tourism activities in Pangandaran. Then it is hoped that this model can also be applied to other coastal areas, such as in the northern coastal region of Bintan Island. Considering the more cloudy physical conditions there and the concentration of the preservation of coral reefs which were initiated by Banyan Tree Bintan, Corporate Social Responsibility (CSR). So with great expectation this model can also be applied to this region in partnership with the CSR Banyan Tree Bintan.

\section{CONCLUSION}

1. The condition of coral reefs in the Pananjung Nature Reserve area is considered unhealthy considering that there are many findings of corals that have been bleached, broken, water conditions and cloudy visibility, sparse coral reef cover, even ornamental fish are rarely found. It is suspected that these conditions are a result of behavior patterns of tourists and communities that are not environmentally friendly, as well as environmental physical factors such as strong underwater currents, high waves, as well as extreme climate and weather.

2. The Pangandaran community in general does not know about the conservation of coral reefs, especially the benefits of conservation, considering that there are still many ignorant community behaviors such as not throwing garbage and other wastes into the sea, fishermen dropping anchors in coral reefs, fishing in the area coral reefs, and also small boat traffic in the coral reef area.

3. Coral reef cultivation techniques that can be applied based on existing problems, namely the amount of plastic waste from millions of tourists who come, can be collaborated as material to design coral reef demonstration plots, which are mineral water and instant noodle waste which is made from cement which will later be used as a substrate . so that it can reduce the impact of environmental degradation, namely the accumulation of waste in the Pangandaran area.

4. The form of the implementation of coral reef cultivation can be carried out in several forms and stages, starting from training to the community in the form of FGDs, then the next training is coaching the creation of a coral gardening tour that is synergized with snorkeling.

\section{Further Program}

1. The condition of damaged coral reef ecosystems requires recovery efforts with concrete steps, which involve all stakeholders well starting from routine outreach activities, training, workshops, and making ecotourism-based tourism activity packages that are synergized with snorkeling activities such as coral reef planting conservation tour package.

2. It is necessary to provide guidance to the community in general regarding the importance of coral reef conserva]tion and guidance to snorkel facilitators regarding the procedures for guiding tourists to pay attention to aspects that can damage coral reefs.

3. The physical model of the coral reef demonstration plot needs to be continuously built by collaborating raw materials from waste to reduce the volume of waste and also to overcome environmental degradation, especially in the waters of the Pananjung Nature 
Journal of Indonesian Tourism, Hospitality and Recreation --- Volume 2, No. 2, October 2019

Reserve by involving sponsors who care about the environment and the community.

4. There needs to be special attention from the Pangandaran Regency Government regarding the issue of coral reef sustainability by making strict regulations for things that can damage coral reefs and also clear zoning arrangements so that coral reef areas are not disturbed by activities that can damage the coral reefs.

\section{REFERENCE}

Johan, dkk. 2007. Terumbu Karang di Indonesia. Yogyakarta: Universitas Atma Jaya Yogyakarta

Kholish. 2003. Terumbu Karang di Indonesia. Yogyakarta: Universitas Atma Jaya Yogyakarta

Pasanea, Y. 2013. Kondisi Terumbu Karang Dan Penyusunan Konsep Strategis Pengawasan Ekosistem Terumbu Karang di Pulau Mansinam Kabupaten Manokoari. Universitas Hasanuddin.

Richards, G., \& Hall, D. (2002). The community: a sustainable concept in tourism development?. In Tourism and sustainable community development (pp. 19-32). Routledge.

Suharsono. 1998. Conditions of coral reef resources in Indonesia. J Pesisir Lautan Vol. 1 No. 2. PKSPL-IPB. Bogor.

Sunarto. 2006. Keanekaragaman Hayati dan Degradasi Ekosistem Terumbu Karang (Karya Ilmiah). Fakultas Perikanan dan Ilmu KelautanUniversitas Padjajaran. Bandung.

World Tourism Organization.2002. Tourism Highlights. UNWTO. Edition 2002

Wirakusuma, R. M. (2014). Analisis kegiatan ekonomi kreatif di kawasan wisata bahari Pulau Tidung Kepulauan Seribu. Jurnal Manajemen Resort dan Leisure, 11(1), 49-58.

Yusnita, Ika. 2014. Kajian Potensi Dampak Wisata Bahari Terhadap TerumbuKarang di Kelurahan Pulau Panggang,Kepulauan Seribu. Tesis,
FakultasPerikanan dan Ilmu kelautan. IPB

Internet Source

Dokumentasi Media Harapan Rakyat pada Kegiatan Pelatihan Budidaya Terumbu Karang.Tersedia di https://www.harapanrakyat.com/2018/0 9/terumbu-karang-di-pantaipangandaran-perlu-diselamatkan/ [diakses pada 11/12/2018]

Instagram Post Beranda Pangandaran. https://www.instagram.com/p/BoGrYJh nqyY/?utm_sources=ig share sheet\&ig shid=10ix145yf4vpu [diakses pada 11/12/2018]

di

